\title{
„Na ciechańskiej plebanii”. Historia ocalenia Zofii Trembskiej. Studium przypadku
}

Podstawową trudnością w opisaniu przypadków udzielania pomocy Żydom przez wiejskich proboszczów jest uboga baza źródłowa. Najbardziej znane są postaci duchownych, którym nadano tytuł Sprawiedliwego wśród Narodów Świata. Jednak i ich historie są zazwyczaj opisane przez skrótowe, schematyczne w formie i treści relacje odznaczonych lub ich podopiecznych. W tym kontekście historia ukrywania się Lili Flachs w domu prawosławnego księdza Jana Lewiarza jest fascynującą wielowymiarową opowieścią. Opowiada o losach żydowskiej dziewczyny i prawosławnego proboszcza narodowości polskiej udających ukraińskie rodzeństwo w łemkowskiej wsi, chronionych przez autorytet ukraińskiego nacjonalisty, który był przyjacielem księdza. Z pewnością wiele innych historii jest równie poruszających, lecz tylko nieliczne są tak dobrze udokumentowane.

Szczegółowe relacje pochodzą od obu stron. W Archiwum Yad Vashem znajduje się świadectwo Zofii Trembskiej ${ }^{1}$ (czyli Lili Flachs, która po wojnie nie powróciła do swojego żydowskiego imienia i nazwiska), złożone w 1961 r. Parę lat później, w 1964 r., do Żydowskiego Instytutu Historycznego wpłynęła relacja księdza Jana Lewiarza $^{2}$. Oba wspomnienia powstały niezależnie od siebie, nie łączy ich żaden wspólny cel, jak to ma miejsce w przypadku ubiegania się o tytuł Sprawiedliwego. Każdy z autorów przedstawia wojenne losy ze swojej perspektywy, co umożliwia poznanie wersji wydarzeń zarówno uratowanej, jak i udzielającego pomocy. Dodatkowym, niezwykle cennym i dającym całkowicie nowe spojrzenie, źródłem jest przeprowadzony w maju 2009 r. wywiad z Zofią Trembską ${ }^{3}$. Jego zestawienie z relacją złożoną dla Yad Vashem blisko pięćdziesiąt lat wcześniej ukazuje znaczące różnice nie tyle w warstwie faktograficznej, ile w podejściu emocjonalnym autorki do osoby księdza. Porównanie obu świadectw Zofii Trembskiej daje szansę prześledzenia ewolucji pamięci o okresie ukrywania się i relacjach z jej głównym opiekunem.

\footnotetext{
${ }^{1}$ Archiwum Yad Vashem (dalej: AYV), 03/1823, Relacja Zofii Trembskiej.

${ }^{2}$ Archiwum Żydowskiego Instytutu Historycznego (dalej: AŻIH), 301/6006, Relacja Jana Lewiarza.

${ }^{3}$ Wywiad z Zofią Trembską, przeprowadzony w maju 2009 r. przez Kamilę Dąbrowską dla Muzeum Historii Żydów Polskich w ramach projektu Polish Roots in Israel.
} 
Problem pamięci i rekonstrukcji wydarzeń po latach dotyczy wszystkich przedstawionych powyżej źródeł, ponieważ pochodzą one z okresu powojennego. Jedynym materiałem z epoki, powstałym hic et nunc, dającym badaczowi niecodzienne możliwości interpretacji, są zdjęcia zrobione w czasie ukrywania się ${ }^{4}$. Poza walorami dokumentacyjnymi i ilustracyjnymi, zdjęcia pełnią rolę wehikułu czasu - oddają atmosferę tamtych dni, dostarczają dodatkowych treści, o których nie mówi żadne pisane świadectwo.

\section{Pierwsze spotkanie}

Była wczesna jesień 1942 roku. Lwowskie getto przeszło już przez dwie akcje likwidacyjne, podczas których Niemcy wywieźli do obozu zagłady w Bełżcu ok. 60 tys. osób. 18-letnia Żydówka Lila Flachs wsiadła do tramwaju jadącego na przedmieścia Lwowa. Zajechawszy na pętlę, usiadła na stojącej opodal ławce. Odczekała piętnaście minut. Potem z powrotem weszła do tramwaju i przekradła się do getta. Owe piętnaście minut były decydujące dla jej dalszych losów. Niewidoczny obserwator miał obejrzeć siedzącą na ławce dziewczynę i rozstrzygnąć, czy zechce ją ukryć i uratować od zagłady. Na szczęście była blondynką i miała „dobry wygląd”. Weryfikacja wypadła pomyślnie.

Kim był ów tajemniczy protektor in spe? Tego Lila nie wiedziała, nie była nawet do końca świadoma, że jest obserwowana. Spotkanie na pętli tramwajowej zaaranżował jej wuj, który obiecał, że wyciągnie dziewczynę z getta i umieści po stronie aryjskiej. Wuj Joachim Morgenstern był, oprócz ojca Jana Flachsa, jednym z ostatnich bliskich Lili, którzy pozostali jeszcze przy życiu. Jej matka została wywieziona do Bełżca podczas akcji sierpniowej w 1942 r. Joachim Morgenstern dzięki żonie Amerykance posiadał paszport obywatela Gwatemali. W okupowanym Lwowie był internowany w specjalnym obozie dla Żydów - obywateli innych państw. Przebywał w lepszych warunkach niż jego krewni w getcie i miał większą swobodę w poruszaniu się i kontaktach z aryjską stroną. Handlował między innymi z Polakiem Janem Lewiarzem, kierownikiem bursy dla chłopców we Lwowie. Jan pochodził ze wsi Fredropol niedaleko Przemyśla. Przed wojną studiował teologię w Przemyślu ${ }^{5}$, chciał zostać księdzem. Według Zofii Trembskiej miał być duchownym rzymskokatolickim, jednak z niewyjaśnionych przyczyn nie mógł nim zostać. W 1940 r. przedłożył wobec soboru biskupów greckokatolickich we Lwowie pracę zatytułowaną Pobyt Izraelitów w Egipcie w świetle archeologii ${ }^{6}$. W relacji Lewiarz tłumaczy, że do kościoła greckokatolickiego zniechęcił go udział Ukraińców w pogromie Żydów we Lwowie w czerwcu 1941 r., którego był świadkiem. Wówczas przystąpił

\footnotetext{
${ }^{4}$ Zdjęcia znajdują się w posiadaniu Zofii Trembskiej.

${ }^{5}$ Wg służbowego formularza wypełnionego przez Jana Lewiarza po wojnie, ukończył teologię w 1933 roku: Prawosławne Archiwum Metropolitalne, Formularz służbowy: ksiądz - kanonik Lewiarz Jan, sygn. XVII9 602A, k. 14.

${ }^{6}$ Ibidem.
} 
do kościoła prawosławnego ${ }^{7}$. Zofia twierdzi, że istotny był w tym kontekście fakt, iż w czasie wojny Watykan wstrzymał święcenia duchownych rzymsko- i greckokatolickich. Najbardziej osiągalne dla Jana Lewiarza było otrzymanie święceń kapłańskich w kościele prawosławnym, który również w czasie okupacji powoływał nowych duchownych ${ }^{8}$. Jedyną przeszkodą były opłaty związane ze święceniami, na które Lewiarz nie miał pieniędzy 9 .

Joachim Morgenstern, wysłuchawszy historii niedoszłego księdza, zaproponował Polakowi układ: zapłaci za jego święcenia na prawosławnego kapłana, w zamian zaś Jan zaopiekuje się jego siostrzenicą i przechowa ją po stronie aryjskiej. Po obejrzeniu Lilki siedzącej na ławce i stwierdzeniu, że jej wygląd nie budzi podejrzeń, Lewiarz postanowił zgodzić się na propozycję wuja dziewczyny. Według powojennej relacji Zofii Trembskiej Jan, oprócz sfinansowania święceń kapłańskich, miał otrzymywać miesięcznie $300 \mathrm{z}^{10}$ przesyłanych pocztą przez przyjaciela wuja, lekarza ze Lwowa ${ }^{11}$. Dodatkowo wuj przekazał jednorazowo pewną kwotę na wyposażenie przyszłego księdza w odzież i sprzęty codziennego użytku na plebanii. Niestety informacje o powyższych warunkach umowy pochodzą jedynie od Zofii Trembskiej, która nie uczestniczyła bezpośrednio w transakcji. Jan Lewiarz, opisując pomoc udzieloną Lilce, nie wspomina w ogóle o jakimkolwiek finansowym aspekcie tego przedsięwzięcia.

W ciągu dwóch kolejnych miesięcy Jan Lewiarz zdał egzaminy w Warszawie i został wyświęcony na księdza prawosławnego. Poprosił o przydzielenie mu parafii w najmniejszej i najbardziej zapadłej wsi. Zofia Trembska podkreśla w obu danych przez siebie świadectwach, że było to $\mathrm{z}$ jego strony poświęcenie $\mathrm{w}$ celu zapewnienia jej bezpieczeństwa. Chodziło o znalezienie schronienia w położonej na uboczu, zapomnianej przez wszystkich miejscowości, gdzie Lilka nie musiałaby utrzymywać kontaktów z dużą liczbą miejscowych. Poza tym objęcie niepozornej parafii zmniejszało ryzyko wzbudzenia zawiści wśród innych duchownych. Ostatecznie zdecydowano, że świeżo wyświęcony kapłan otrzyma przydział do Ciechanii - górskiej wioski w powiecie krośnieńskim. W międzyczasie Jan Lewiarz przekazał Lilce dokumenty swojej zmarłej na gruźlicę siostry. Od tej pory Lila Flachs była Zofią Lewiarz, siostrą prawosławnego księdza. Już nigdy nie powróciła do swojego prawdziwego imienia.

\footnotetext{
${ }^{7}$ AŻIH, 301/6006, Relacja Jana Lewiarza, s. 1.

${ }^{8}$ Spośród 153 księży prawosławnych przebywających w powojennej Polsce 21 otrzymało święcenia kapłańskie w latach 1940-44 - dane na podstawie ankiety przeprowadzonej w latach 1953-54, za: K. Urban, Kościót prawosławny w Polsce 1945-1970, Kraków 1996, s. $189-190$.

${ }^{9}$ Transkrypcja wywiadu z Zofią Trembską, maj 2009 r., MHŻP (Polish Roots in Israel), s. 3,4 .

10300 zł miesięcznie to bardzo mała kwota jak na zapłatę za ukrywanie. Być może było to $3000 \mathrm{zł}$.

${ }^{11}$ AYV, 03/1823, Relacja Zofii Trembskiej, s. 21.
} 


\section{Ciechania}

Na przełomie października i listopada 1942 r. na lwowskim dworcu kolejowym pojawiła się grupka podróżnych: prawosławny ksiądz w sutannie, dziewczyna z czarnym jamnikiem na rękach i młody mężczyzna niosący walizki. „Stało mnóstwo Żydów z getta, którzy wyłapywali Żydów dla Gestapo” - wspomina Zofia Trembska. - „Strasznie się bałam tego kontrolowania, że oni mnie poznają. Wystarczyło, że oni kiedyś mnie widzieli w getcie"12. Jednak na szczęście wsiedli do pociągu bez przeszkód. Dobrym kamuflażem okazał się pies Aks, ulubieniec księdza. „Jaki Żyd by ciągnął psa ze sobą?"13 - pyta retorycznie Zofia Trembska.

Mężczyzna, który towarzyszył im w podróży, był kochankiem księdza Lewiarza. Ukrainiec Roman Hawrylak zamieszkał z księdzem i jego siostrą na plebanii jako ich brat cioteczny. Zofia szybko zorientowała się, że relacje między jej opiekunami wykraczają poza zwykłą przyjaźń. Jednak dopiero po pół roku wspólnego życia na plebanii dowiedziała się z encyklopedii Zagadnienia seksualne o istnieniu związków homoseksualnych ${ }^{14}$.

Roman Hawrylak pochodził ze znanej rodziny ukraińskich nacjonalistów spod Przemyśla. Jego obecność miała być swoistym parawanem ochronnym dla Polaka Jana i Żydówki Lilki, ich uwiarygodnieniem w łemkowskiej wsi, jaką była Ciechania. „Wśród działaczy ukraińskich, jak ja powiedziałam Hawrylak, że jest moją rodziną, to to już było jak zaklęcie”15 - tłumaczy Zofia Trembska. Warto podkreślić, że nie tylko Lilka vel Zosia ukrywała swoją tożsamość. W podobnej sytuacji znalazł się ksiądz Lewiarz, który od momentu przybycia do Ciechanii (a być może jeszcze wcześniej) funkcjonował jako Ukrainiec. Obojgu udało się otrzymać ukraińskie kenkarty już w trakcie pobytu na wsi, co, oprócz obecności Romka, stanowiło dodatkowe zabezpieczenie.

Według spisu powszechnego z 1921 r. Ciechanię zamieszkiwało 305 osób, z czego 304 były narodowości rusińskiej. Tylko jeden respondent podał narodowość polską i wyznanie rzymskokatolickie ${ }^{16}$. Być może był nim nauczyciel J. Orłowski, który pojawia się w przedwojennych źródłach jako informator władz państwowych o antypolskiej działalności miejscowych księży greckokatolickich ${ }^{17}$. Nie wiadomo jednak, czy w czasie okupacji polski nauczyciel nadal mieszkał we wsi. W świa-

12 Transkrypcja wywiadu z Zofią Trembską, maj 2009 r., loc. cit., s. 9.

${ }^{13}$ Ibidem.

${ }^{14}$ Ibidem, s. 7.

${ }^{15}$ Ibidem, s. 5.

${ }^{16}$ Skorowidz miejscowości Rzeczypospolitej Polskiej opracowany na podstawie wyników pierwszego Powszechnego spisu ludności z dnia 30 IX 1921 r. i innych źródet urzędowych, tom XIII, Województwo lwowskie, Warszawa 1924, s. 19.

${ }^{17}$ Dokumenty Ministerstwa Wyznań Religijnych i Oświecenia Publicznego (MWRiOP), Archiwum Akt Nowych, sygn. 929, s. 482, za: J. Moklak, Łemkowszczyzna w Drugiej Rzeczypospolitej. Zagadnienia polityczne i wyznaniowe, Kraków 1997, s. 177. 
dectwach Zofii Trembskiej i Jana Lewiarza nie pojawiają się żadni Polacy żyjący w Ciechanii. Podobnie nieobecni byli Żydzi, którzy według spisu z 1921 r. nielicznie zamieszkiwali okoliczne wsie ${ }^{18}$. Największe skupisko ludności żydowskiej znajdowało się w miasteczku Żmigród Nowy, ok. $15 \mathrm{~km}$ od Ciechanii ${ }^{19}$. Z drugiej strony Zofia Trembska wspomina, że cała wieś ukrywała miejscowego Żyda, który przechodził od jednego gospodarza do drugiego. Przy wjeździe do wsi stał dom pożydowski, na którego podwórku została zamordowana rodzina żydowska. Chłopi, którzy przejeżdżali obok tego gospodarstwa, zdejmowali czapki i żegnali się ${ }^{20}$.

Być może Żydzi nie budzili wśród mieszkańców Ciechanii negatywnych emocji. Przyczyną tego stanowiska była nie tylko znikoma obecność Żydów w życiu wsi. Można przypuszczać, że głównym problemem występującym w przedwojennej społeczności Ciechanii był wewnętrzny antagonizm wśród Łemków pomiędzy wyznawcami tendencji rusofilskiej a zwolennikami ruchu narodowo-ukraińskiego ${ }^{21}$. Obie zwalczające się koncepcje bardzo silnie łączyły się z religią. Propagujący ideę Łemków jako członków wspólnoty narodu ruskiego znajdywali zazwyczaj wsparcie u przedstawicieli kościoła prawosławnego. Duchowni greckokatoliccy natomiast sprzyjali działaczom ukraińskim. Według spisu powszechnego z 1921 r. wszyscy mieszkańcy Ciechanii byli wyznania greckokatolickiego. Podobnie wyglądała sytuacja we wszystkich innych miejscowościach na Łemkowszczyźnie. Niestety, nie dysponujemy równie szczegółowymi statystykami ze spisu w 1931 r. Obraz, który wyłoniłby się z danych zanotowanych dziesięć lat później, z pewnością znacząco różniłby się od tego z $1921 \mathrm{r}$. W międzyczasie bowiem doszło do tzw. schizmy tylawskiej, kiedy w drugiej połowie lat dwudziestych, idąc za przykładem ludności z Tylawy, wiele wsi łemkowskich przeszło masowo na prawosławie. Wśród nich była też Ciechania ${ }^{22}$. Nie oznaczało to, że wspólnota greckokatolicka przestała tam istnieć. Wręcz przeciwnie, w przedwojennych dokumentach ksiądz greckokatolicki z Ciechanii jest wymieniany jako mocno zaangażowany w ruch ukraiński ${ }^{23}$. Rów-

${ }^{18}$ We wsi Polany: na 910 mieszkańców 9 osób podało wyznanie mojżeszowe; we wsi Olchowiec: na 402 wszystkich mieszkańców 7 osób podało wyznanie mojżeszowe. Warto zauważyć, że w obu wsiach żadna osoba nie podała narodowości żydowskiej (zadeklarowane narodowości to: rusińska, polska, niemiecka - 1 osoba, inna - 3 osoby), Skorowidz miejscowości Rzeczypospolitej Polskiej..., tom XIII, Województwo lwowskie, Warszawa 1924, s. 19.

${ }^{19}$ Żmigród Nowy: na 1959 mieszkańców 709 osób narodowości żydowskiej, jednocześnie 940 zadeklarowało wyznanie mojżeszowe, Skorowidz Miejscowości Rzeczypospolitej Polskiej..., tom XII, Województwo krakowskie i Śląsk Cieszyński, Warszawa 1925.

${ }^{20}$ Wywiad uzupełniający, rozmowa telefoniczna autorki z Zofią Trembską, 8 czerwca 2009.

${ }^{21}$ Więcej na ten temat: E. Michna, Łemkowie - grupa czy naród, Kraków 1995.

${ }^{22}$ D. Nowak, Przyczynek do historii greckokatolickiego dekanatu dukielskiego [w:] „Płaj. Almanach karpacki”, nr 30 (wiosna 2005).

${ }^{23}$ Między innymi ksiądz greckokatolicki w Ciechanii nie odmówił obowiązkowej modlitwy za pomyślność Rzeczypospolitej Polskiej i Prezydenta RP, za: J. Moklak, op. cit., s. 119, 171. 


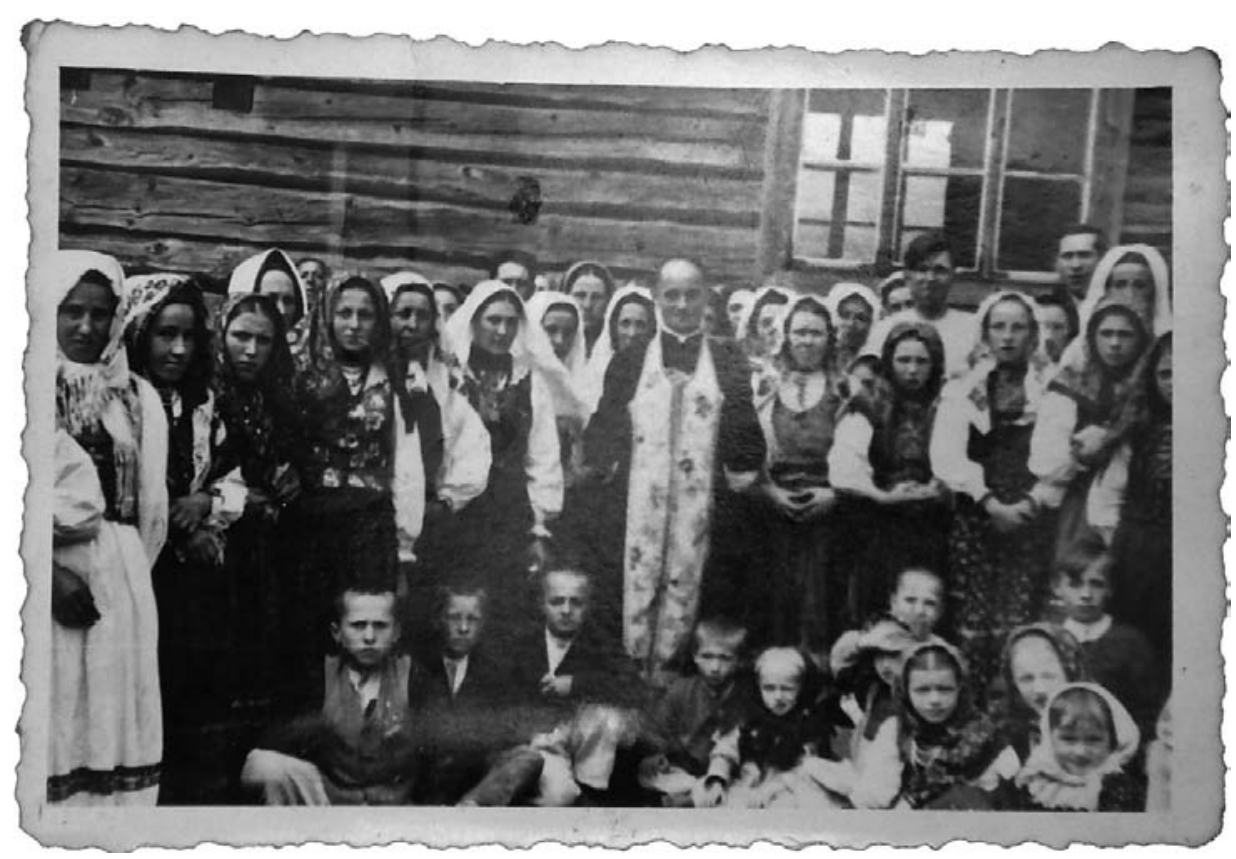

Ks. Jan Lewiarz z łemkowską ludnościa Ciechanii, 1942 lub 1943 r.

nolegle Ciechania była jedną z aktywniejszych wsi pod względem inicjatyw rusofilskich, w które zaangażowani byli księża prawosławni ${ }^{24}$.

Oznaczało to, że we wsi działały dwa silne ośrodki ideologiczne i religijne, stojące w opozycji do siebie, a jednocześnie nastawione wrogo do Państwa Polskiego. Trudno stwierdzić, jaki realny wpływ miały te dwie tendencje na świadomość i codzienne życie mieszkańców Ciechanii. Jednak dla sytuacji nowo przybyłego prawosławnego księdza Lewiarza i jego siostry Zofii duże znaczenie miał ciągnący się od przedwojennych czasów konflikt z miejscowym księdzem greckokatolickim. Mógł on bowiem stanowić dodatkowe zagrożenie. W kontekście antypolskich wystapień mających miejsce w przeszłości w Ciechanii ${ }^{25}$ nie do przecenienia była rola Romka Hawrylaka, którego nazwisko oddalało wszelkie podejrzenia od rodzeństwa Lewiarzy.

Obok religii, język był drugim istotnym wyznacznikiem wspólnoty Łemków. W oparciu o te dwa elementy Rusini galicyjscy budowali swoje poczucie przynależ-

${ }^{24}$ W Ciechanii odbył się lokalny zjazd partii rusofilskiej RSO (Ruska Seljanska Organizacja - Ruska Organizacja Wiejska, założono czytelnię Kaczkowskiego propagującą ruch rusofilski wśród Łemków, wymieniany jest też prawosławny ksiądz T. Munczakewycz jako aktywny działacz na rzecz czytelni Kaczkowskiego, współpracujący z działaczami RSO, za: J. Moklak, op. cit., s. 54, 83, 98, 99.

${ }^{25}$ Zob. przyp. 23. 
ności do wschodniego kręgu kulturowego, a zarazem odrębności od sąsiadujących z nimi Polaków ${ }^{26}$. Dlatego dla mieszkańców plebanii bardzo ważna okazała się znajomość ukraińskiego. Już podczas podróży furmanką z Jasła do Ciechanii stał on się jedynym obowiązującym językiem. „Chłop [który przyjechał po nich do Jasła Z. S.-K.] już mówił po ukraińsku i wszyscy przeszli na ukraiński. A ja w ogóle nie byłam przygotowana, że ja będę musiała mówić po ukraińsku"27 - wspomina Zofia Trembska, która jako jedyna z całej trójki nie znała tego języka. Zanim go się nauczyła, przekręcała polski na ukraińską nutę. „Oni [miejscowi - Z. S.-K.] się ze mnie śmieli. [...] Mówili, że ja mówię jakimś dialektem, którego nie rozumieją”. Na szczęście Zosia nie znała jidysz, więc nie było ryzyka, że wtrąci przez przypadek żydowskie słowo. Niemniej jednak sytuacja była dla mieszkańców wsi niecodzienna: siostra prawosławnego proboszcza, Ukrainka, nie mówi po ukraińsku! Aby zaspokoić ich ciekawość, Zosia opowiadała, że nie wychowywała się z resztą rodzeństwa Lewiarzy, ale została zabrana pod opiekę bogatego wuja do dużego miasta, gdzie chodziła do polskiej szkoły i zapomniała ukraińskiego. Ludzie uwierzyli w tę historię lub udawali, że uwierzyli ${ }^{28}$.

\section{Na plebanii}

Podział ról pomiędzy domownikami plebanii ustalił się już pierwszego poranka po przybyciu do Ciechanii. Kiedy Zosia wstała, jej dwóch towarzyszy jeszcze spało. W kuchni, gdzie stało jej łóżko, było bardzo zimno. Jednak zamiast napalić w piecu, dziewczyna ubrała się, usiadła i zaczęła robić na drutach dla zabicia czasu. Jak tłumaczy po latach, nie przyszło jej do głowy, by zająć się kuchnią, przygotować śniadanie czy pościelić własne łóżko. Będąc rozpieszczoną jedynaczką, nie była nauczona zajmować się gospodarstwem. Obaj mężczyźni po przebudzeniu byli mocno zdziwieni tym stanem rzeczy: „Pierwszy wstał Romek, wszedł do kuchni. Ogień wygaszony, ziąb jak nieszczęście, a ja siedzę i robię na drutach... [...] On na mnie spojrzał, poszedł, poszeptali coś tam z Jankiem. Przyszedł Janek mnie oglądać. [...] Spojrzał na mnie, nic nie powiedział, wyszedł. Za chwilę Romek się ubrał i zrobił śniadanie, nakrył do stołu. [...] Później Janek chce się myć, a tu nie ma wody: »Romek, nie ma wody« - mnie nawet do głowy nie przyszło, że to mogło mnie dotyczyć. Dopiero... poszedł Romek po wodę. I tak już zostało”29 opowiada Zofia Trembska.

Poranne zachowanie Zosi musiało poważnie naruszyć wizję domowego porządku, jaką mieli ksiądz i jego przyjaciel. Mężczyźni zapewne spodziewali się, że dorastająca panna zajmie się prowadzeniem domu. Tymczasem okazało się, że ich podopieczna nie ma pojęcia o gospodarskich obowiązkach i nie jest też świadoma,

\footnotetext{
${ }^{26}$ E. Michna, op. cit., s. 34.

${ }^{27}$ Transkrypcja wywiadu z Zofią Trembską, maj 2009 r., loc. cit., s. 10.

${ }^{28}$ AYV, 03/1823, Relacja Zofii Trembskiej, s. 22.

${ }^{29}$ Transkrypcja wywiadu z Zofią Trembską, maj 2009 r., loc. cit., s. 13.
} 
czego od niej oczekują. Pod jednym dachem spotkali się przedstawiciele różnych warstw społecznych: wychowana w domu zamożnych lwowskich sklepikarzy Zosia posługiwała się innym kodem kulturowym, miała inne nawyki i rozumienie swojej roli. Pochodzącym z chłopskich rodzin Jankowi i Romkowi trudno było wyobrazić sobie, że 18-letnia dziewczyna nie umie napalić w piecu. Z drugiej strony potrafiła elegancko nakryć do stołu i ułożyć wyszukane menu dla gości. Ponadto nie interesowały jej pieniądze, co mogło świadczyć, w ich mniemaniu, że nigdy jej ich nie brakowało i nie musiała się o nie troszczyć. Odmienny status społeczny Zosi jej opiekunowie przyjęli z szacunkiem i podziwem: „Później podsłuchałam taką rozmowę: „Ona jest taka wielka pani, że ona nawet nie rozumie, że ma po sobie posprzątać«. To im zaimponowało”30 - opowiada Zofia Trembska.

Nie zajmowała się gospodarstwem. Do jej nielicznych obowiązków, jako siostry księdza, należał wypiek kuleczek z ciasta, które Lewiarz podawał swym parafianom jako komunię świętą. Ksiądz śmiał się z absurdalności tej sytuacji: Żydówka przygotowuje komunię dla prawosławnych ${ }^{31}$.

Wkrótce ksiądz i Romek zaczęli planować wyjazd do Lwowa, żeby przywieźć starą służącą Hanię, która miała prowadzić gospodarstwo. Zosia nalegała, by razem z Hanią sprowadzili do Ciechanii jej ojca. Uciekła się do szantażu, mówiąc, że jeśli nie zgodzą się przywieźć ojca, wtedy ona wraca do Lwowa, gdyż sama tu nie wytrzyma. Ostatecznie Janek i Romek ulegli jej namowom. Wrócili po tygodniu ze służącą i Janem Flachsem, który czekał na wyrobienie mu aryjskich dokumentów. Oficjalnie był przedstawiany miejscowym jako chory umysłowo wujek. Gospodarstwo księdza liczyło już pięcioro domowników.

Członkowie tej rodziny-nie rodziny dalecy byli od wyjawiania własnych tajemnic, nawet sobie nawzajem. „To były takie dziwne stosunki, tam o wielu rzeczach się nie mówiło, to było tak dobrze, że nie trzeba było o wielu rzeczach wiedzieć" 32 mówi Zofia Trembska. O Hani wiedziała jedynie, że była przed wojną służącą. W czasie okupacji sowieckiej we Lwowie ukrywała Jana Lewiarza, który z niewyjaśnionych przyczyn był prześladowany przez ówczesne władze. Ksiądz przykazał Zosi, by za te zasługi okazywała Hani szacunek. Stara służąca nie wiedziała natomiast o żydowskim pochodzeniu dziewczyny i jej ojca. Obowiązywała wersja, że Zosia jest córką polskiego oficera, który musi się ukrywać. Hania była poczciwą i bardzo pracowitą kobietą. Przejęła gospodarskie obowiązki Romka, który często podróżował, by handlować. „My byśmy chyba zgnili z brudu, jak Romek wyjechał [...] my z księdzem do roboty, to żeśmy nie byli”33.

Zastanawiając się nad wspólnym funkcjonowaniem mieszkańców plebanii, należy wziąć pod uwagę nie tylko ich odmienne narodowości, pochodzenie społeczne i kulturowe, ale także wyraziste i niełatwe charaktery domowników. Centralną po-

\footnotetext{
${ }^{30}$ Ibidem; AYV, 03/1823, Relacja Zofii Trembskiej, s. 22.

${ }^{31}$ Rozmowa autorki z Zofią Trembską 24 stycznia 2010 r. w Tel Awiwie.

32 Transkrypcja wywiadu z Zofią Trembską, maj 2009 r., loc. cit., s. 25.

${ }^{33}$ Ibidem, s. 17.
} 
stacią był ksiądz Lewiarz, mężczyzna w wieku czterdziestu lat ${ }^{34}$, według opisu Zofii przystojny, choć „miał coś dziwnego w twarzy”. Jego dawna podopieczna ocenia go po latach jako człowieka bardzo inteligentnego, o dużej wiedzy, która mogła imponować. Jednocześnie wielokrotnie podkreśla jego wybuchowy charakter, używając określeń „furiat” i „histeryk”. Jan był skory do wszczynania kłótni, do których, jak można przypuszczać, często dochodziło.

Główna oś konfliktu przebiegała między proboszczem a Zofią, która bardzo szybko przestała być onieśmieloną, zahukaną panienką. Jak sama o sobie mówi, była rozpieszczoną nastolatką, „pyskowała” księdzu, dyktując własne warunki. Posuwała się do szantażu (zwłaszcza kiedy nie było już z nimi jej ojca): „Jak będziesz na mnie krzyczał, to ja to zniosę, [...] ale żebyś wiedział: w momencie, jak mnie uderzysz, to mnie jest wszystko jedno, ja mogę jutro pójść na gestapo i się zameldować. Co ja tracę? Tylko siebie, a wy pójdziecie wszyscy”"35. Ksiądz nie pozostawał jej dłużny, wyzywając ją od najgorszych. Awantury te z pewnością nie sprzyjały przyjaznej atmosferze, jednak hardością i uporem Zofia zdobyła wysoką pozycję w domowej hierarchii, była osobą, z która należało się liczyć.

Odmiennie ukształtowała się sytuacja w przypadku jej ojca, który od początku potulną i uniżoną postawą oraz wykonywaniem wszelkich prac domowych starał się zaskarbić sobie przychylność gospodarzy. Efekt tych poczynań był odwrotny ksiądz nie szanował Jana Flachsa, pomiatał nim, dokuczał mu ${ }^{36}$. W wywiadzie z 2009 roku Zofia opowiada także o innym problemie: ojciec miał dobry wygląd, mówił po ukraińsku, był dowcipny, wesoły, ludzie we wsi bardzo go szanowali, natomiast nie mógł się nauczyć przeżegnać. „Myśmy robili lekcje: »Wujku, przeżegnaj się!« [...] i nie mógł się nauczyć. To było coś psychicznego” - wspomina Zofia.

Z pewnością ojciec nie potrafił tak dobrze dostosować się do nowego otoczenia jak córka. Starali się ograniczać jego kontakty z miejscowymi, mówili, że wujek jest chory psychicznie, miewa napady i musi wtedy być zamknięty w pokoju. Później jego udział w życiu wsi został jeszcze zredukowany, za sprawą jednego słowa, które niebacznie wypowiadał. Jan Flachs cały czas przekręcał imię zaprzyjaźnionego chłopa, nazywając go „Bobik” zamiast „Bobek”. W czasie jednego z wieczornych spotkań z parafianami Bobek, śmiejąc się, powiedział do niego: „Wujku, naucz się, ja nie jestem Bobik! Wszystkie Żydy w Żmigrodzie też mówiły na mnie Bobik”37. Po tym wydarzeniu przerażony ksiądz nakazał wujkowi jak najmniej mówić. Przez cały czas pobytu w Ciechanii Jan Flachs nie posiadał aryjskich dokumentów, co dodatkowo zwiększało ryzyko dekonspiracji.

Trudno stwierdzić, jaki był generalny stosunek księdza do Żydów. Wiadomo, że gdy kłócił się ze starą Hanią, nazywał ją „żydowską służącą”, co traktował jako

${ }^{34}$ Data urodzenia 23 IV 1903 r.: Prawosławne Archiwum Metropolitalne, Formularz służbowy: ksiądz - kanonik Lewiarz Jan, sygn. XVII9 602A, k. 14.

35 Transkrypcja wywiadu z Zofią Trembską, maj 2009 r., loc. cit., s. 26.

${ }^{36}$ AYV, 03/1823, Relacja Zofii Trembskiej, s. 23.

37 Transkrypcja wywiadu z Zofią Trembską, maj 2009 r., loc. cit., s. 16. 
obelgę. Według Zofii ksiądz nie pałał nienawiścią do Żydów, ale też specjalnie za nimi nie przepadał. Miał wiedzę na temat kultury i historii Żydów, znał trochę hebrajski, zapewne w związku z pracą, którą napisał podczas studiów teologicznych „Pobyt Izraelitów w Egipcie w świetle archeologii”38. Matka księdza, która jako jedyna z rodziny Lewiarzy wiedziała, że jej syn ukrywa Żydów, odwiedziła ich parę razy w Ciechanii. Zosia wspomina ją jako miłą, dobrą kobietę, która ubolewała nad jej losem ${ }^{39}$.

Wydaje się, że w przeciwieństwie do Jana Romek Hawrylak był łagodnego usposobienia. Trzeba jednak przyznać, że jego rola była o tyle łatwiejsza, że często wyjeżdżał i nie musiał znosić napiętej atmosfery na co dzień. Zosia wypowiada się o nim bardzo ciepło, zaznaczając jednocześnie, że był ukraińskim nacjonalistą. Potrafił w gniewie podczas kłótni z księdzem grozić mu, że doniesie na niego do Niemców o ukrywaniu Żydów. Wtedy ojciec Zosi pobił go i dusił tak długo, aż Romek obiecał, że ich nie wyda ${ }^{40}$. Pomijając ten incydent, Zofia twierdzi, że był dla niej dobry „tak jak brat”, współczuł jej, choć nie pokazywał tego po sobie. Mówi, że był dla niej oparciem życiowym, także w latach powojennych ${ }^{41}$.

\section{Miejscowi}

Zastanawiające jest funkcjonowanie tak zróżnicowanej grupy, tworzącej teoretycznie jedną rodzinę, w małej, zamkniętej społeczności wiejskiej bez wzbudzenia jakichkolwiek podejrzeń ze strony miejscowych. „Lud z Ciechanii był prosty i łatwo było ukryć się, bo nikogo nic nie obchodziło”42 - twierdzi ksiądz Lewiarz w swojej relacji. Słowa te potwierdza Zofia Trembska: „Na ogół było przyjęte o nic nie pytać. [...] Ja nie wiem, czy nikogo to nie interesowało...?”43. Z pewnością brak dociekliwości i podejrzliwości ze strony mieszkańców wsi stanowił okoliczność sprzyjającą ukrywaniu się. Prawdopodobnie wynikał on po części z charakteru społeczności Łemków - zamkniętej, bez szerszej orientacji, pozostającej na uboczu, daleko od centrum wydarzeń. Wspomniana niechęć do zadawania pytań mogła też być efektem wojennej specyfiki tych terenów. Górskie tereny Łemkowszczyzny były w owym czasie przystanią i schronieniem dla życiowych rozbitków, ludzi z różnych przyczyn wyjętych spod prawa. Wśród miejscowej śmietanki, którą poznali ksiądz i jego „rodzina”, byli inteligenci z carskiej Rosji, którzy zbiegli przed represjami bolszewików, księża wyrzuceni z katolickiego kościoła za nadużywanie alkoholu i związki z kobietami, polski lekarz ze Lwowa, ukrywający się wraz ze swoją żoną Żydówką...

${ }^{38}$ Wywiad uzupełniający, rozmowa telefoniczna autorki z Zofią Trembską, 8 czerwca 2009.

${ }^{39}$ Transkrypcja wywiadu z Zofią Trembską, maj 2009 r., loc. cit., s. 15.

${ }^{40}$ Rozmowa autorki z Zofią Trembską 24 stycznia 2010 r. w Tel Awiwie.

${ }^{41}$ Ibidem, s. 15, 31.

${ }^{42}$ AŻIH, 301/6006, Relacja Jana Lewiarza, s. 5.

${ }^{43}$ Transkrypcja wywiadu z Zofią Trembską, maj 2009 r., loc. cit., s. 23. 


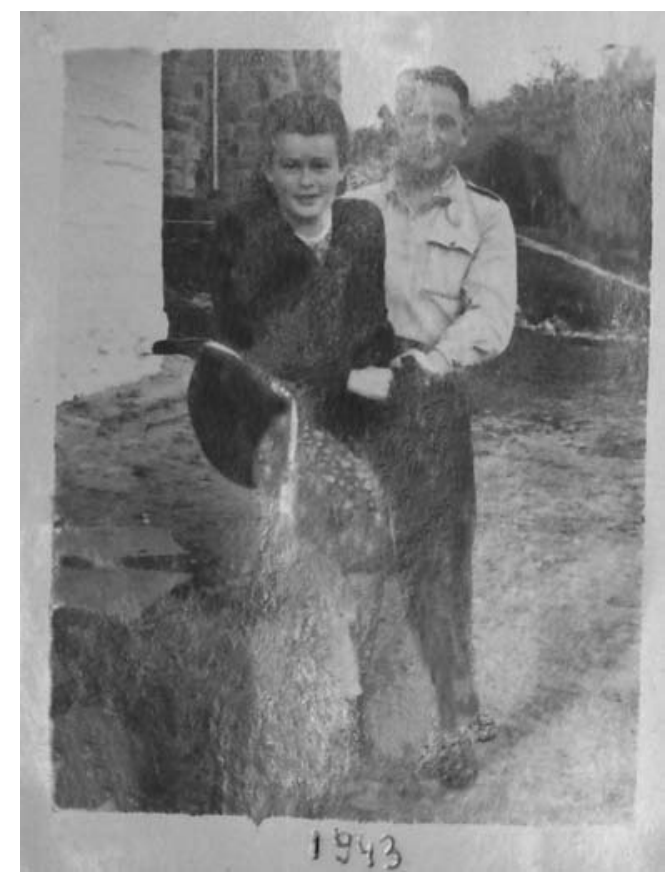

Lila Flachs (w czasie wojny Zofia Lewiarz) ze swoim ukraińskim narzeczonym Włodzimierzem Bajko, Ciechania lub Bartne, 1942-1944 r.

Dodatkowym czynnikiem oddalającym podejrzenia była wysoka pozycja proboszcza w miejscowej hierarchii autorytetów: poważanie i przychylność, którymi był obdarzany niejako „z urzędu” przez wiernych. Kontakty księdza Lewiarza i jego „rodziny” z parafianami były bliskie i częste. Niemal każdego wieczoru Łemkowie schodzili się na plebanię ,jak do kawiarni” - według słów Zosi, siedzieli bez światła i gawędzili. Nie mniej intensywne były spotkania z inteligencją z okolicznych wsi: nauczycielami, duchownymi, lekarzem, aptekarzem... „To wszystko było nasze towarzystwo, które należało zapraszać i poznawać [...] jeździło się z wizytami w rozmaite święta" ${ }^{44}$ - opowiada Zofia. Sami również wyprawiali przyjęcia dla gości. „Mieliśmy bujne życie towarzyskie tam” - podsumowuje.

Na jednym ze spotkań Zosia poznała Włodzimierza Bajko, starszego o pięć lat Ukraińca, dyrektora szkoły w pobliskiej wsi Polany. Zakochała się w nim z wzajemnością. Jako narzeczona gościła u jego rodziny, która była zachwycona taką dobrą partią: siostra księdza, grzeczna panienka. Ksiądz Lewiarz zapewne niechętnie patrzył na związek Zosi, stanowiący potencjalne zagrożenie dla ich tajemnicy. Jednak nie wypowiadał się na jego temat. „Udawał, że on nie widzi. To było chyba najmądrzejsze, co mógł zrobić”45 - stwierdza Zofia. Zdecydowała się na wyjawie-

\footnotetext{
${ }^{44}$ Ibidem, s. 13 .

${ }^{45}$ Ibidem, s. 23.
} 
nie prawdy o swoim pochodzeniu Włodkowi, kiedy front był już blisko. Ukochany zareagował z przerażeniem, szybko opuścił plebanię, by zapewne więcej tam nie wrócić. „Do dzisiaj nie wiem, czy on był taki cudowny, jak ja go widziałam, jak byłam zakochana, czy on był takie zero, jak ja to dzisiaj widzę. [...] to była normalna ucieczka i tchórzostwo"46 - komentuje po latach Zofia.

\section{Niemcy}

W bezpośrednim sąsiedztwie plebanii, po drugiej stronie drogi, znajdowała się siedziba niemieckiej straży granicznej (Ciechania była położona przy granicy polsko-czechosłowackiej). W koszarach stacjonowało około dwudziestu żołnierzy. Niektórzy z nich byli stałymi uczestnikami życia towarzyskiego na plebanii. W powojennych świadectwach Zofii i Jana istnieją trzy sprzeczne ze sobą wersje zainicjowania kontaktów towarzyskich z Niemcami. W relacji z 1961 r. Zofia Trembska twierdzi, że zawarcie znajomości z żołnierzami było pomysłem księdza, który wysłał ją z wizytą grzecznościową do koszar ${ }^{47}$. Inaczej to wydarzenie wspomina Lewiarz: „Każdego wieczoru przychodzili Niemcy po Zosię ażeby szła tańczyć. Skoro raz zabroniłem, bo obawiałem się że ją tam zgwałcą, przyszedł niemiec nazwiskiem Luman i omal nie przebił mnie bagnetem, a dostałem ile wlazło. Od tego czasu Zosia do nich chodziła, a mnie było już łatwiej z wyżywieniem, bo Zosia przynosiła od nich mięso i inne prowianty"48. Natomiast w wywiadzie z $2009 \mathrm{r}$. Zofia przyznaje, że pierwsza wizyta u Niemców była jej pomysłem. Chciała w ten sposób zdobyć chleb, którego nie można było dostać we wsi ${ }^{49}$. Ta ostatnia wersja wydaje się najbardziej prawdopodobna.

Po nawiązaniu znajomości żołnierze zaczęli być częstymi gośćmi na plebanii, przynosili niemieckie gazety, chleb i naftę. Jeden ze strażników, Georg Spławski, polubił się z Zosią, szczerze rozmawiał z nią o swoich komunistycznych przekonaniach i nienawiści wobec hitleryzmu. Inny żołnierz zaprzyjaźnił się z Janem Flachsem do tego stopnia, że gdy ten wyjechał do Warszawy, Niemiec posyłał mu paczki z różnymi dobrami. Wspólnie bawiono się na plebanii: „oni mnie obtańcowywali, a ksiądz grał na akordeonie"50 - wspomina Zosia.

Pamiątką po znajomości z niemieckimi żołnierzami są zdjęcia wykonane w Ciechanii latem 1943 r. Większość spośród dziesięciu fotografii została zrobiona aparatem zaprzyjaźnionego Georga Spławskiego i podarowana Zosi. Przedstawiają one księdza Lewiarza w otoczeniu mieszkańców wsi, Spławskiego z dzieckiem łemkowskim na rękach, Zosię na spacerze z niemieckimi żołnierzami lub przebraną w tradycyjny strój łemkowski (podobno ludność Ciechanii była zachwycona, gdy

\footnotetext{
${ }^{46}$ Ibidem, s. 21, 22.

${ }^{47}$ AYV, 03/1823, Relacja Zofii Trembskiej, s. 23.

${ }^{48}$ AŻIH, 301/6006, Relacja Jana Lewiarza, s. 5.

${ }^{49}$ Transkrypcja wywiadu z Zofią Trembską, maj 2009 r., loc. cit., s. 17.

${ }^{50}$ Ibidem, s. 18.
} 


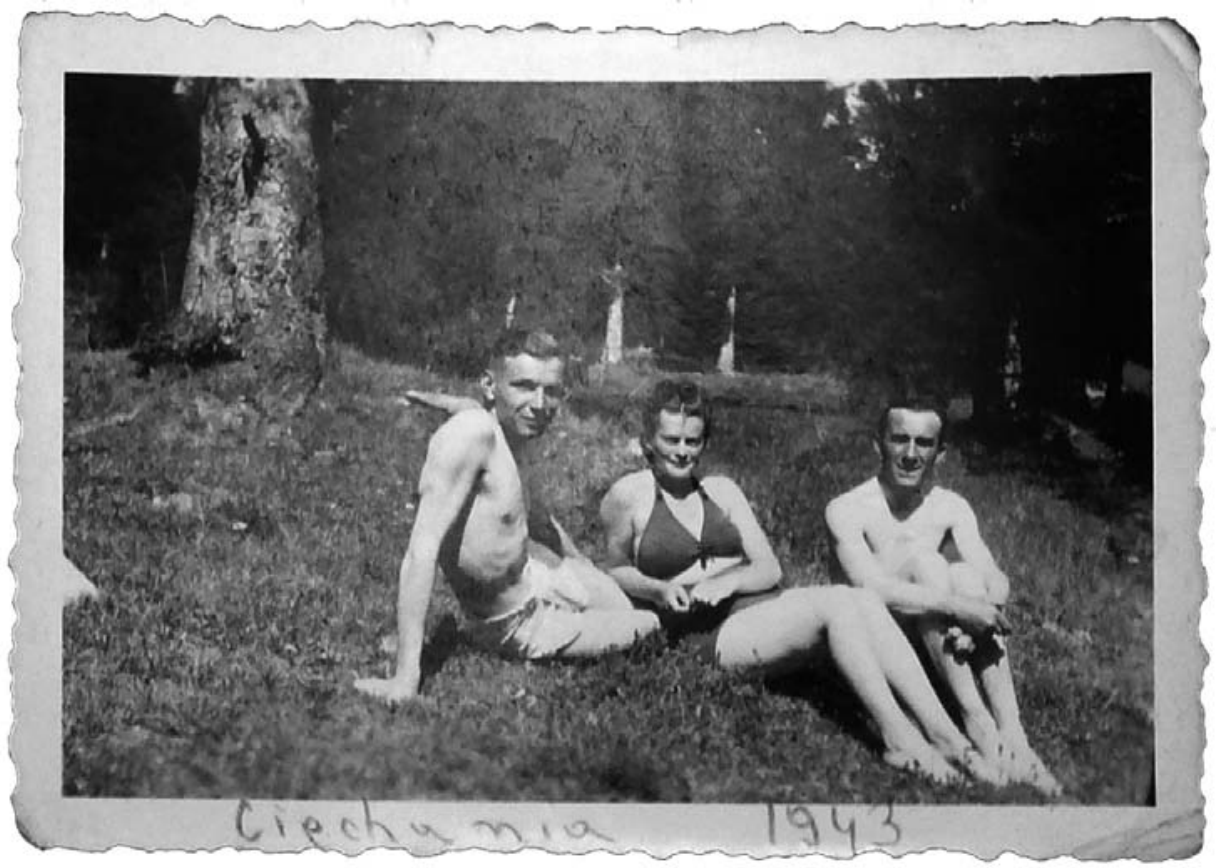

Lila Flachs (w czasie wojny Zofia Lewiarz) z Romanem Hawrylakiem (po prawej) i niemieckim żotnierzem Georgiem Sptawskim (po lewej), Ciechania, lato $1942 \mathrm{r}$.

przyszła tak przebrana do cerkwi)... Zatrzymane na kliszy chwile tchną spokojem i sielską atmosferą. Zosia siedzi na łące pomiędzy Romkiem Hawrylakiem a Georgiem Spławskim. Wszyscy w kostiumach kąpielowych, uśmiechnięte twarze, oczy lekko zmrużone w pełnym słońcu. Żydowska dziewczyna, Ukrainiec i niemiecki żołnierz podczas przyjacielskiej przechadzki, połączeni nieoczekiwanym splotem okoliczności wojennych.

Zażyłość prawosławnego księdza z niemieckimi żołnierzami wpisywała się w ogólną linię polityczną przyjętą przez zwierzchników Kościoła prawosławnego na ziemiach polskich. Metropolita Dionizy oficjalnie deklarował lojalność wobec władz Generalnego Gubernatorstwa i za ich przyzwoleniem wspierał ukrainizację prawosławia ${ }^{51}$. Choć wśród Łemków poczynania te nie znalazły poparcia, wydaje się, że bliskie kontakty ks. Lewiarza z Niemcami nie musiały budzić szczególnych kontrowersji we wsi.

Najwięcej podejrzeń i spekulacji powodowało wystawne życie mieszkańców plebanii, które kontrastowało ze skromnym uposażeniem prowincjonalnego proboszcza. „Ksiądz prawosławny nie miał takiej pensji, żeby żyć tak, jak myśmy żyli” -

${ }^{51}$ Więcej na ten temat: A. Mironowicz, Kościót prawostawny na ziemiach polskich w XIX i XX wieku, Białystok 2005, s. 201-206; K. Urban, op. cit., s. 57-63. 
tłumaczy Zofia. - „Oni byli pięknie ubrani - wszyscy, łącznie ze mną. [...] Przyjęcia robiło się huczne i wielkie”52. „Rodzina” księdza nie cierpiała nędzy i głodu. Zosia wyglądała tak dobrze, że jej ojciec, przyjechawszy do Ciechanii, po dwumiesięcznej rozłące $z$ córką, myślał, że jest ona w ciąży ${ }^{53}$. Comiesięczne przekazy pieniężne wysyłane przez przyjaciela wuja Joachima zapewniały wszystkim domownikom dostatnie życie.

Początkowe założenia księdza Lewiarza, którymi kierował się przy wyborze parafii, w rzeczywistości nie były realizowane. Odseparowanie Zosi od miejscowych nie powiodło się. Wręcz przeciwnie - prowadziła bardzo intensywne życie towarzyskie, z udziałem żołnierzy niemieckich włącznie. Natomiast drugie postanowienie, by nie prowokować zawiści innych, zostało zniweczone przez zbytek i luksusy, nieprzystające wiejskiemu duchownemu. Miejscowy ksiądz greckokatolicki oskarżył prawosławnego kapłana o nielegalne źródło dochodów. Na szczęście jego domysły poszły w kierunku dalekim od prawdy - doniósł ukraińskiej policji, że mieszkańcy prawosławnej plebanii zajmują się szpiegostwem (zapewne na rzecz Sowietów ${ }^{54}$ ). Policja przeprowadziła rewizję. Jedyną podejrzaną rzeczą, którą znaleziono, były mapki przesuwającego się frontu. Zosia przerysowywała je w wolnych chwilach przez szkło z niemieckich gazet. Razem z Romkiem została osadzona w areszcie w pobliskiej wsi Krempna. Pomimo iż zaprzyjaźnieni żołnierze niemieccy zaświadczyli, że kopiowanie map było jedynie zabawą, dopiero znacząca łapówka dostarczona przez Janka umożliwiła zwolnienie aresztowanych. Wydaje się, że środki na przekupienie policji pochodziły od Jana Flachsa. Zosia w relacji dla Yad Vashem mówi wręcz o wyłudzeniu przez księdza pokaźnego pierścienia od ojca ${ }^{55}$. We współczesnym wywiadzie wspomina o pierścieniu, ale bez sprecyzowania jego źródła pochodzenia. W świadectwie księdza znaleźć można jedynie enigmatyczne stwierdzenie: „zebrałem nieco grosza i policja ukraińska zwolniła ją”6 .

Ukraińska policja szczęśliwie nie wylegitymowała Jana Flachsa, który cały czas nie miał aryjskich papierów. Dopiero potem Jan Lewiarz załatwił odpowiednie dokumenty u greckokatolickiego księdza Orskiego - Polaka, który wcześniej był księdzem rzymskokatolickim, jednak został wyrzucony z kościoła za pijaństwo i kontakty z kobietami. Najprawdopodobniej znał prawdziwą historię Zofii i jej ojca. Po otrzymaniu papierów Jan Flachs postanowił wyjechać do Warszawy, by tam ukryć się po stronie aryjskiej. Okoliczności i motywy podjęcia tej decyzji są różnie przedstawiane w świadectwach Zofii. Jako bezpośrednia przyczyna wskazywane jest powstanie w okolicy Ukraińskiej Powstańczej Armii (UPA), która ogłosiła werbunek ludności cywilnej do swoich szeregów. Istniała obawa, że ojciec, uchodzący za

52 Transkrypcja wywiadu z Zofią Trembską, maj 2009 r., loc. cit., s. 19.

${ }^{53}$ Ibidem, s. 16.

${ }^{54}$ Oskarżenia tego typu ze strony duchowieństwa greckokatolickiego wobec przedstawicieli orientacji rusofilskiej zdarzały się też w innych miejscowościach na Łemkowszczyźnie; więcej na ten temat: E. Michna, op. cit., s. 43.

${ }^{55}$ AYV, 03/1823, Relacja Zofii Trembskiej, s. 24.

${ }^{56}$ AŻIH, 301/6006, Relacja Jana Lewiarza, s. 2. 
Ukraińca, zostanie powołany do UPA i zdekonspirowany ${ }^{57}$. W relacji Yad Vashem Zofia podaje jako równie ważny czynnik spotęgowanie szykan wobec ojca ze strony księdza, który chciał w ten sposób zmusić go do opuszczenia plebanii. Jednak w późniejszym wywiadzie nie ma już mowy o złym traktowaniu. Sam ksiądz wypowiada się o wyjeździe Jana w tonie lekceważącym: „Ukrywał się ponad rok, aż zachciało mu się pojechać do Warszawy"58.

Ojciec przebywał w Warszawie od kwietnia 1943 do sierpnia 1944. Cały czas korespondowali z Zosią. Jan Flachs zaprzyjaźnił się z ks. Orskim, który w tym okresie został przeniesiony na warszawską Pragę. Ojciec Zofii odwiedzał go co parę dni. Listy przychodzące do Ciechanii były coraz bardziej dramatyczne, ojciec w zakonspirowany sposób dawał do rozumienia, że „mu się ziemia pali pod nogami” ${ }^{59}$. W międzyczasie akcja werbowania do UPA uspokoiła się. Można było z powrotem sprowadzić ojca na plebanię. W tym celu Zosia i Romek pojechali do Warszawy. Niestety przybyli za późno. Mieszkanie - melinę, w której ukrywał się ojciec wraz z innymi ludźmi - zastali puste. Dowiedzieli się od sąsiadów, że parę dni wcześniej wszyscy lokatorzy zostali aresztowani za słuchanie radia. Była to ostatnia wiadomość o losie ojca. Zrozpaczona Zosia wraz z Romkiem jak najszybciej wsiedli do powrotnego pociągu. Wiedzieli, że „coś się szykuje” i że są to ostatnie chwile, by wydostać się z Warszawy. „Wśród moich Ukraińców panowały wręcz paniczne nastroje, gdyż obawiali się Polaków bardziej niż Niemców”60 - relacjonuje Zofia. Dzień później wybuchło powstanie warszawskie.

Po stracie ojca Zosia załamała się, przez parę dni cały czas spała, nic nie jadła. Nie mogła otwarcie rozpaczać, gdyż to mogłoby wydać się podejrzane miejscowym. Jej opiekunowie podeszli do jej stanu ze zrozumieniem: „Hania mi przynosiła ciepłe mleko do sadu i spałam. I oni mnie tak dali spać, żebym się uspokoiła, żebym nie płakała"61.

\section{Bartne}

W międzyczasie, kiedy ojciec Zosi był w Warszawie, ksiądz Lewiarz postarał się o przeniesienie do większej i bogatszej parafii. Jesienią 1943 r. cała „rodzina” proboszcza przeniosła się do Bartnego w powiecie gorlickim. Według niemieckiego spisu przeprowadzonego w marcu 1943, wieś zamieszkiwało 912 osób $\mathrm{b}^{62}$. Brak danych dotyczących składu narodowościowego wsi w czasie wojny. Można jedynie

57 Transkrypcja wywiadu z Zofią Trembską, maj 2009 r., loc. cit., s. 21; AYV, 03/1823, Relacja Zofii Trembskiej, s. 25.

${ }^{58}$ AŻIH, 301/6006, Relacja Jana Lewiarza, s. 2.

${ }^{59}$ Transkrypcja wywiadu z Zofią Trembską, maj 2009 r., loc. cit., s. 24.

${ }^{60}$ AYV, 03/1823, Relacja Zofii Trembskiej, s. 26.

${ }^{61}$ Transkrypcja wywiadu z Zofią Trembską, maj 2009 r., loc. cit., s. 25.

${ }^{62}$ Amtliches Gemeinde- und Dorfverzeichnis für das Generalgouvernement auf Grund der Summarischen Bevolkerungsbestandsaufnahme am 1. Marz 1943, Kraków 1943, s. 22. 
przypuszczać, że, podobnie jak w Ciechanii, wszyscy byli Łemkami ${ }^{63}$. Zofia wspomina, że kiedy przyjechali do Bartnego, w sąsiedztwie plebanii stało opuszczone gospodarstwo pożydowskie. Był to ślad po przedwojennej obecności Żydów we wsi. Gospodarstwa tego zresztą nikt z miejscowych nie chciał przejąć, co według Zofii było świadectwem ich przyzwoitości i dobrego stosunku do Żydów ${ }^{64}$.

Jan objął ładną, dużą plebanię z sadem. Życie jej mieszkańców popłynęło utartym torem. Nadal utrzymywali kontakty towarzyskie z miejscową „śmietanką”. Częstym gościem był ukraiński narzeczony Zosi, Włodzimierz Bajko. Dom księdza odwiedzali też zaprzyjaźnieni żołnierze niemieccy z Ciechanii. Przyjeżdżali do oddalonego o 30 km Bartnego na rowerach, motocyklach lub samochodami, których użyczali również mieszkańcom plebanii do odbywania podróży po okolicy. „Ja osobiście miałam specjalną przepustkę i pozwolenie na korzystanie z niemieckich samochodów"65 - wspomina Zosia. Do jej nowych obowiązków należało pasienie gęsi. Gdy po paru próbach zaprotestowała, twierdząc, że gęsi są wredne i głupie, przydzielono jej pod opiekę dwa barany. Dodatkową pracą Zosi było zajmowanie się dziesięcioma kotami, które hodował ksiądz.

Atmosfera w Bartnem była pełna napięcia i niepewności. Pod koniec 1943 i w 1944 roku partyzanci działali coraz aktywniej, nocami często wychodzili z lasu i pojawiali się we wsi. Według Zofii ksiądz Lewiarz współpracował z jedną z partyzanckich grup - nie wiadomo, czy polską czy rosyjską. Inny z kolei oddział polował na niego. Dlatego w nocy wszyscy domownicy opuszczali plebanię i ukrywali się u różnych gospodarzy w sąsiedztwie. W związku ze zbliżającym się frontem i zajęciem terenów na wschodzie przez Armię Czerwoną połączenia pocztowe zostały przerwane i ustał comiesięczny dopływ pieniędzy ze Lwowa. W relacji dla Yad Vashem Zofia twierdzi, że wobec braku opłat za ukrywanie ksiądz starał się wymusić na niej odejście poprzez psychiczne dręczenie jej i wszczynanie awantur pod byle pretekstem ${ }^{66}$. W wywiadzie z 2009 r. przyznaje, że Jan dokuczał jej, m.in. nazywał ją „darmozjadem”, jednak nie wyrzucił jej i traktował ją na tych samych prawach, jak przedtem ${ }^{67}$. Można jedynie zastanawiać się, czy fakt zablokowania opłat sprawił, że ksiądz poczuł przewagę nad swoją podopieczną i stał się bardziej napastliwy w ich częstych kłótniach.

${ }^{63}$ Wg spisu powszechnego z 1921 r. Bartne liczyło 760 mieszkańców, z czego 748 stanowili Rusini (deklarowane wyznanie greckokatolickie), a 12 - Żydzi (wyznanie mojżeszowe), za: Skorowidz miejscowości Rzeczypospolitej Polskiej opracowany na podstawie wyników pierwszego Powszechnego spisu ludności z dnia 30 IX 1921 roku i innych źródet urzędowych, tom XII, Województwo krakowskie i Śląsk Cieszyński, Warszawa 1925.

${ }^{64}$ Ostatecznie Zofia wraz z księdzem wykorzystali teren tego gospodarstwa pod uprawę (wywiad uzupełniający, rozmowa telefoniczna autorki z Zofią Trembską, 8 czerwca 2009).

${ }^{65}$ AYV, 03/1823, Relacja Zofii Trembskiej, s. 27.

${ }^{66}$ AYV, 03/1823, Relacja Zofii Trembskiej, s. 27.

${ }^{67}$ Wywiad uzupełniający, rozmowa telefoniczna autorki z Zofią Trembską, 8 czerwca 2009. 


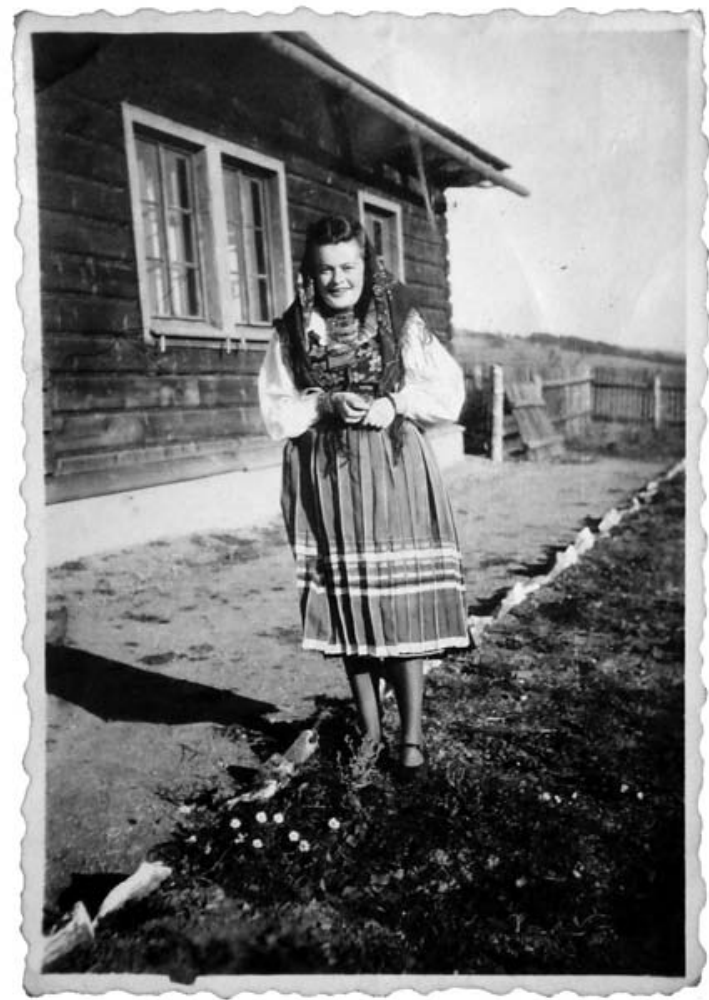

Lila Flachs (w czasie wojny Zofia Lewiarz) w tradycyjnym łemkowskim ubraniu, które założyła do zdjęcia ku uciesze miejscowej ludności, Ciechania, 1942 lub 1943 r.

W opisanych powyżej okolicznościach doszło do awantury, która przesądziła o dalszych losach ukrywania się Zosi. Latem 1944 r. Jan Lewiarz zarzucił jej, że nie nakarmiła kotów, co należało do jej zadań. Dziewczyna upierała się, że spełniła swój obowiązek. Z błahego powodu wywiązała się ostra wymiana zdań. Rozwścieczony ksiądz rzucił się na Zosię, chcąc ją uderzyć. Nie dopuścił do tego Romek, który „skoczył z drugiej strony i tak go [księdza - Z. S.-K.] walnął, że mu wybił zęba"68 - według słów Zofii Trembskiej. Nie namyślając się długo, wrzuciła do torebki szczoteczkę do zębów oraz koszulę nocną. Uciekła z plebanii do Włodzimierza Bajko.

Narzeczony, chociaż wiedział o jej prawdziwym pochodzeniu i był przerażony tą informacją, otoczył ją opieką. Chwilowo zamieszkali w szkole we wsi Polany, której był dyrektorem. Kiedy cała miejscowość została ewakuowana w związku ze zbliżającym się frontem, poszli do domu matki Włodka w Jabłonicy Polskiej pod

${ }^{68}$ Transkrypcja wywiadu z Zofią Trembską, maj 2009 r., loc. cit., s. 27. 
Krosnem. Bajko powiedział matce o tym, że jego narzeczona jest Żydówką. Zofia źle wspomina pobyt w ukraińskiej rodzinie: matka „jak przeszła koło mnie przeżegnywała się i pluła. [...] Jak jego [Włodka - Z. S.-K.] nie było, to w ogóle nie dostawałam jeść, a jak on był, to oni jedli przy stole, a ja w drugim pokoju dostawałam" ${ }^{69}$. Włodek był dla niej dobry, kupował jej perfumy i biżuterię. Nie wiedział, że gdy był w pracy, jego narzeczona nie dostawała jedzenia. W międzyczasie przetoczył się front i na Łemkowszyznę wkroczyła Armia Czerwona. Zosia miała dość kilkumiesięcznego pobytu u matki Włodka. Przeczytała manifest PKWN. Była pod nim podpisana Wanda Wasilewska, którą znali jej rodzice przed wojną. Postanowiła pojechać do Lublina i poszukać dawnych znajomych lub rodziny, którzy mogliby jej pomóc. Bajko odprowadził ją do Krosna, skąd polscy żołnierze przewozili ludność na ciężarówkach. Zofia nigdy więcej nie zobaczyła swojego ukraińskiego narzeczonego. Pożegnanie z nim zamknęło wojenny rozdział w jej życiu.

\section{Po wojnie}

Po wyjeździe do Lublina Zofia tylko raz powróciła na Łemkowszczyznę. Było to jeszcze w latach czterdziestych. Przyjechała z Warszawy do Bartnego, do księdza Lewiarza, by zabrać swoje rzeczy, które zostawiła, uciekając w pośpiechu po awanturze o koty. „Najważniejsza dla mnie była pościel, bo nie mogłam tego zdobyć, nie miałam pieniędzy”70. Ksiądz bardzo serdecznie ją przyjął. „Ja się bardzo nim wzruszyłam, ja byłam bardzo do niego przywiązana”71 - wspomina po latach. Po tym spotkaniu utrzymywali kontakt, który był na tyle bliski, że Jan odradzał swojej dawnej podopiecznej wyjście za mąż za żydowskiego adwokata Aleksandra Trembskiego. Podobno twierdził, że Zosia jest zbyt daleko od środowiska żydowskiego, by mogła się w nim na nowo odnaleźć ${ }^{72}$.

Sam został wysiedlony z Bartnego wraz z całą ludnością łemkowską w ramach akcji „Wisła”. Na Ziemiach Zachodnich ksiądz Lewiarz aktywnie działał na rzecz odbudowy parafii prawosławnych. Zachowały się listy hierarchów kościoła prawosławnego delegujące na początku lat pięćdziesiątych Jana Lewiarza, proboszcza parafii w Zimnej Wodzie, do organizowania życia religijnego w różnych miejscowościach ${ }^{73}$. Z tego okresu pochodzi pozytywna opinia księdza dziekana, przełożonego Lewiarza: „Nadzwyczaj dobry, sumienny i wykształcony pasterz. [...] Cieszy się autorytetem [...] na terenie całego dekanatu, a przede wszystkim u narodowości łemkowskiej. Głęboko przywiązany do prawosławia i bardzo pożyteczny na Ziemiach Zachodnich dla autorytetu prawosławia"74.

\footnotetext{
${ }^{69}$ Ibidem, s. 28 .

${ }^{70}$ Ibidem, s. 32.

${ }^{71}$ Ibidem.

${ }^{72}$ Wywiad uzupełniający, rozmowa telefoniczna autorki z Zofią Trembską, 8 czerwca 2009.

${ }^{73}$ Dokumenty Prawosławnego Archiwum Metropolitalnego, za: K. Urban, op. cit.

74 Prawosławne Archiwum Metropolitalne, Formularz służbowy: ksiądz - kanonik Lewiarz Jan, sygn. XVII9 602A, k. 15.
} 
Według dokumentów Urzędu do Spraw Wyznań w drugiej połowie lat pięćdziesiątych Lewiarz nakłaniał wysiedlonych Łemków do powrotu do Bartnego i odzyskania swojej parafii, urządzał zbiórki pieniędzy na remont tamtejszej cerkwi, zorganizował przyjazd wysiedlonych do Bartnego i odprawił tam nabożeństwo ${ }^{75}$. Działania te były wbrew polityce ówczesnych władz, które, jak się wydaje, przywołały księdza do porządku. Od tego czasu Lewiarz stał się „mężem zaufania” Urzędu do Spraw Wyznań, deklarował chęć współpracy z władzami, donosił o niepożądanych działaniach na rzecz ożywienia wspólnoty greckokatolickiej na swoim terenie $^{76}$. Jego sprawozdania mogły mieć wpływ na negatywne rozpatrzenie przez władze próśb grekokatolików o restytuowanie ich placówek duszpasterskich i na decyzję o przyznaniu wyłączności w tej kwestii kościołowi prawosławnemu ${ }^{77}$.

Kontakty księdza Lewiarza z władzami zaznaczyły się jeszcze wyraźniej w latach sześćdziesiątych, kiedy został przeniesiony do Sanoka. Jako dziekan dekanatu rzeszowskiego wystawiał oceny wpisujące się w kampanię władz, oskarżających ludność cywilną i duchownych greckokatolickich i prawosławnych o nacjonalizm ukraiński. Według opinii badaczy tej problematyki wiele jego działań przyczyniło się do nasilenia antagonizmów polsko-ukraińskich na szczeblach władze państwowe - duchowieństwo, duchowni - wierni, a także pomiędzy samymi duchownymi ${ }^{78}$. Ksiądz Lewiarz był wspierany przez władze państwowe, które proponowały go jako kandydata na biskupa nowo utworzonej diecezji sanocko-przemyskiej. Ostatecznie jednak zrezygnowano z powołania tej diecezji, prawdopodobnie w obawie przed rozbudzeniem konfliktów narodowościowych ${ }^{79}$.

W 1956 r. Zofia wyjechała wraz z mężem i dwiema córkami do Izraela, gdzie mieszka do dziś. Korespondencja z Janem Lewiarzem trwała, choć jak się wydaje, nie była zbyt regularna. „Pisze rzadko. Prosiłem ją o kawę i kadzidło. Obiecała a nie wysłała. [...] Jestem samotny i wiele mi nie potrzeba" 80 - skarży się ksiądz w liście z 1964 r. do ŻIH-u. „Jeżeli chodzi o pisanie listów, to jestem w tych rzeczach bardzo chaotyczna" ${ }^{81}$ - wyznaje Zofia. W pewnym momencie otrzymała informację, że ksiądz potrzebuje pomocy finansowej. Nie mogła jednak jej udzielić, gdyż właśnie zmarł jej mąż i sama była w trudnej sytuacji materialnej. „Kazała mi zgłosić się do Warszawy do Jointu i przyjechać do Palestyny. Ale to nie na możliwości prawosławnego księdza”82 - pisze Lewiarz. Zofia Trembska twierdzi, że wizyta Jana w Izraelu była już przygotowana, jednak wybuch wojny sześciodniowej i późniejsze zerwanie stosunków dyplomatycznych między oboma państwami zniweczyły te plany.

\footnotetext{
${ }^{75}$ Archiwum Akt Nowych (dalej: AAN), Urząd ds. Wyznań, sygn. 21, k. 1, 4, 5, 7.

${ }^{76}$ Por. list Jana Lewiarza z 20 XI 1956, AAN, Urząd ds. Wyznań, sygn. 21, k. 2, 3.

${ }^{77}$ K. Urban, op. cit., s. 177.

${ }^{78}$ Ibidem, s. 316.

${ }^{79}$ Ibidem, s. 157.

${ }^{80}$ AŻIH, 301/6006, Relacja Jana Lewiarza, s. 3.

${ }^{81}$ Wywiad uzupełniający, rozmowa telefoniczna autorki z Zofią Trembską, 8 czerwca

${ }^{82}$ AŻIH, 301/6006, Relacja Jana Lewiarza, s. 3.
} 2009. 
Od tego momentu nie mieli już ze sobą kontaktu. Jakiś czas potem Zofia otrzymała wiadomość o śmierci księdza.

$$
* * *
$$

Historia ocalenia Lili Flachs i jej późniejszych stosunków z księdzem Lewiarzem nie poddaje się wyraźnej klasyfikacji w kategoriach dobra i zła. Ukazuje całe bogactwo postaw i zachowań w sytuacjach skrajnych, często wymykającym się kanonom, w które wpisuje się przypadki ratowania Żydów przez duchownych. Jednak właśnie dlatego, że tak trudno o jednoznaczną ocenę, historia ta jest bardzo ludzka i autentyczna. Jej siła w dużym stopniu polega na narracji samej bohaterki Lili Flachs vel Zofii Trembskiej, która po latach szczerze i z dystansem opowiada o swoich wojennych losach. Weryfikuje własne zeznanie złożone w Yad Vashem pięćdziesiąt lat wcześniej. Tłumaczy, że przedstawiona przez nią wówczas skrajnie negatywna ocena księdza wynikała z zapamiętanego jej stosunku do niego w czasie ukrywania się. „To była relacja jak pomiędzy zbuntowaną nastolatką i jej rodzicami. Ja byłam bardzo zbuntowana, nie byłam przyzwyczajona do wsi, nie znosiłam dwulicowości księdza, który ukrywał swoją tożsamość lub np. podjadał ukradkiem, kiedy my musieliśmy pościć. [...] Był furiatem, nie było łatwo z nim żyć pod jednym dachem"83. Takiej a nie innej treści relacji Yad Vashem sprzyjała ogólna atmosfera w Izraelu lat sześćdziesiątych, zwłaszcza wśród polskich Żydów, często przyjeżdżających z Polski na skutek antysemickich szykan, których tam doświadczyli.

Z biegiem lat stosunek Zofii do Jana stawał się coraz bardziej łagodny i wyrozumiały. Zaczęła patrzeć na wojenną sytuację bardziej obiektywnie, dostrzegać jej całościowy wymiar, bez koncentrowania się wyłącznie na wyrwanych z kontekstu szczegółach. W odległym Izraelu ksiądz stawał się jej coraz bliższy, jak pisała w jednym z listów do niego: „w miarę upływu lat czuję się dziwnie związana z Tobą i Twoim domem i chwilami doprawdy zdaje mi się, że zostawiłam tam bliską rodzinę" 84 . Sama Zofia Trembska nie potrafi jednoznacznie stwierdzić, który wizerunek Jana Lewiarza jest bliższy prawdy: czy ten naszkicowany przez nią, kiedy była zbuntowana i rozżalona, czy ten, który rysuje jej się po latach, gdy patrzy z większym dystansem. Jednego natomiast jest pewna: „Wie Pani, co mnie męczy najbardziej w życiu? Że ja mojemu księdzu nigdy nie powiedziałam »dziękuję«"85. Zaraz potem dodaje zdanie, które stanowi kwintesencję relacji między ukrywanymi a ich opiekunami: „A ja bym tak chciała porozmawiać, jak on mnie wtedy widział, nie tylko, jak ja jego. To są rzeczy nie do odrobienia w życiu”86.

${ }^{83}$ Wywiad uzupełniający, rozmowa telefoniczna autorki z Zofią Trembską, 8 czerwca 2009.

${ }^{84}$ Fragment listu Zofii Trembskiej do Jana Lewiarza z 16 IV 1963, AŻIH, 301/6006, Relacja Jana Lewiarza, s. 4.

${ }^{85}$ Transkrypcja wywiadu z Zofią Trembską, maj 2009 r., loc. cit., s. 32.

${ }^{86}$ Ibidem, s. 34. 


\title{
Słowa kluczowe
}

Relacje polsko-żydowskie, Zagłada, ratowanie Żydów, Ciechania

\begin{abstract}
The article is a case study of hiding Lila Flachs in the house of an Orthodox priest, Jan Lewiarz. It tells the story of a Jewish girl and an Orthodox priest of Polish nationality pretending to be Ukrainian siblings in a Lemko village and protected by the authority of a Ukrainian nationalist who was the priest's friend. The confluence of the fate of a Pole, a Jewess and a Ukrainian, and their complex relations give a picture of reality with many hues of grey, with no black-white divisions. There are few stories of saving Jews by village priests that are documented so well. The wealth of sources produced at different times and by different people, allows not only a detailed examination and reconstruction of the story, but also an in-depth penetration into the relations between the protagonists, study of the influence of memory on the content and character of the story.
\end{abstract}

\section{Key words}

Polish-Jewish relations, Holocaust, rescuing Jews, Ciechania 